\title{
Intellectual capital role in supporting competitive advantage for sports clubs in Alexandria
}

\section{Amin Mahmoud Gaafar}

Lecture, sports administration \& recreation, faculty of physical education for men, Alexandria University, Egypt

\section{Research problem}

The intellectual capital is the key set of development, when the gap occurs between him and the rest of the capital must be interest in him and through the interest in human beings in terms of training and preparation and deepen the experience and support of administrative capacity, while the human setting to the fullest, it becomes easy development and support the capacity of the rest of the capital, so must the aspirant countries to the growth and progress of work on the development and increased attention to the head of intellectual capital.

The Intellectual Capital has become in light of this competitive economy, the information age is the real capital of the organizations as a corner which plays a key role in the innovation process, which is the leader in the process of change and innovation, and thus is capable of turning knowledge into value and then into a competitive advantage, which means that the center of gravity in the generation of value has moved from the exploitation of natural resources (physical) to the exploitation of intellectual assets (intangible) and diminishing returns Act (which applies to material goods) to increase returns Act (with respect to knowledge and ideas. (6: 44 )

Competitive advantage is the area that the organization has the ability higher than its competitors in exploiting foreign opportunities or reduce the impact of threats, and derive competitive advantage from the organization's ability to exploit the physical or human and intellectual resources, it may be related to quality or technology or the ability to reduce the cost or marketing efficiency.

The intellectual capital management entrance made for building and achieving competitive advantage of the organization and maintain, it requires dealing with three basic data are: the application of the organization's strategy, to deal positively with change and build a strategic unity of the organization.

It confirmed some studies the results of the importance of intellectual capital in the institutions and working to increase the competitive advantage including Sami Fayyad study (2008) (3) entitled "Capital of knowledge and its impact on the causes of the strategic success of the business organizations" study moen Almaadida and Osman Mohamed (2008) (8 ) entitled "The impact of operations knowledge capital management in strategic innovation," study Abdullah Kazem (2008) (4) entitled "The impact of the intellectual capital in creativity Altnzemi", Mjarjor Mcgregor.j study. tewed, d.and pach (2001) (14) entitled "The impact of the intellectual capital on corporate governance".

The researcher believes that in light of this great importance of intellectual capital, and in the size of the sports investments sports clubs, and in light of the scarcity of resources, 
which has become one of the major determinants, in the midst of acute and which is the basic feature of the economic environment of competition, it became necessary to draw the attention and consider sports clubs province Alexandria to recognize the importance of intellectual capital and the need to work on its development as a major key to any problem and commander of management and other resources, so as to ensure the continuity of the ability to create added value to the organization and to achieve a strong competitive position and drew the attention of sports clubs on the importance of intellectual capital management as a tool to achieve competitive advantage.

\section{Research objectives:}

The role of intellectual capital in support of the competitive advantage of sports clubs in Alexandria

\section{Research queries:}

-Is there a relationship between intellectual capital and competitive advantage of sports clubs in Alexandria?

\section{Research Procedures}

Research Methodology: The researcher used the descriptive survey appropriateness of the nature of the research

research sample: members of boards of "Union and Smouha and the Olympic and Sporting Club management, players and some sports activities" football, volleyball, basketball and gymnastics "technical and administrative system for these games.

Table (1)

The research sample

\begin{tabular}{c|c|c|c|c|c} 
M & \multicolumn{1}{|c|}{ Categories } & $\begin{array}{c}\text { Research } \\
\text { population }\end{array}$ & $\begin{array}{c}\text { Sample } \\
\text { exploratory }\end{array}$ & $\begin{array}{c}\text { Core } \\
\text { sample }\end{array}$ & $\begin{array}{l}\text { Percentage } \\
(\%)\end{array}$ \\
\hline 1 & $\begin{array}{l}\text { Members of the boards of management of } \\
\text { sports clubs and club managers and sports } \\
\text { activities (Ittihad - Olympic - Smouha - } \\
\text { Sporting- Steeds owners) }\end{array}$ & 75 & 15 & 60 & 53.1 \\
\hline 2 & $\begin{array}{l}\text { Personnel management sports activity } \\
\text { clubs }\end{array}$ & 63 & 11 & 52 & 46.9 \\
\hline & Total & 138 & 26 & 133 & 100.0
\end{tabular}

\section{Data collection tools:}

It was used a questionnaire designed

Experts and confined agreement rate to the questionnaire was finalized between $95 \%$ to $100 \%$, after delete and modify the terms of each axis according to expert opinions.

\section{Scientific transaction to form questionnaire}

First: the sincerity of the form: the form has been ratified in two ways account 
A- Believe content: researcher relied on the sincerity of the arbitrators and to identify the appropriate themes and phrases and the extent and duration of clarity, where some of the language has been deleted and modified others, according to expert opinion.

\section{B- sincerity of internal consistency:}

- the correlation coefficients between study dimensions of the total score of the instrument values enjoy a high degree of honesty with the total score of the instrument, and thus conclude from this that these dimensions and content of the paragraphs of the check measurement objectives desired in the questionnaire, and all values correlation coefficients are statistically significant at the significance level (0.01)

Second: Persistence: Persistence and has been found in two ways

Re-application of form was obtained: re-apply the questionnaire after a period (15 days) for the sample of ( 26) randomly selected members of the original community and outside the study sample

Land transactions stability vocabulary values less than the coefficient of stability dimension that belong to any Individual vocabulary that all fixed, as the Individual intervention does not lead to reduced reliability coefficient

Correlation between capital variables (human - structural - capital Relations) and competitive advantage

Table (2) between the correlation coefficients between capital variables (human structural - capital Relations) and competitive advantage from the viewpoint of the members of the boards of directors

\begin{tabular}{|r|l|c|c|c|c|}
\hline $\mathbf{m}$ & \multicolumn{1}{|c|}{ Axes } & $\mathbf{1}$ & $\mathbf{2}$ & $\mathbf{3}$ & $\mathbf{4}$ \\
\hline 1 & The first axis: human capital & & & & \\
\hline 2 & $\begin{array}{l}\text { The second axis: the head of structural } \\
\text { money }\end{array}$ & ${ }^{* *} 0.351$ & & & \\
\hline 3 & The third axis: - capital Relations & ${ }^{*} 0.329$ & ${ }^{*} 0.272$ & & \\
\hline 4 & Theme IV: - competitive advantage & ${ }^{*} 0.284$ & ${ }^{*} 0.298$ & ${ }^{*} 0.285$ & \\
\hline
\end{tabular}

Tabulated value of the correlation coefficient at the level of significance $(0.01)=0.330$, and at a level of significance $(0.05)=0.254$

Seen from the table (2) the presence of correlation at the level of significance $(0.01)$ between human capital, competitive advantage, and at a level of significance (0.05) among all of the top structural capital, and capital relations and between Altnavsh from the viewpoint of the members of the boards of directors feature. 
Table (3) between the correlation coefficients between capital variables (human - structural - capital Relations) and competitive advantage from the standpoint of workers

\begin{tabular}{|c|l|r|r|r|r|}
\hline \multicolumn{1}{|c|}{ Axes } & $\mathbf{1}$ & $\mathbf{2}$ & $\mathbf{3}$ & $\mathbf{4}$ \\
\hline $\mathbf{m}$ & \multicolumn{1}{|c|}{} & & & \\
\hline 2 & The first axis: human capital & $\begin{array}{l}\text { The second axis: the head of structural } \\
\text { money }\end{array}$ & ${ }^{* *} 0.369$ & & \\
\hline 3 & The third axis: - capital Relations & ${ }^{*} 0.284$ & 0.294 & & \\
\hline 4 & Theme IV: - competitive advantage & ${ }^{*} 0.278$ & ${ }^{* *} 0.368$ & ${ }^{*} 0.281$ & \\
\hline
\end{tabular}

Tabulated value of the correlation coefficient at the level of significance $(0.01)=$ 0.361 , and at a level of significance $(0.05)=0.276$

Seen from the table (3) the presence of correlation statistically significant relationship at the level of significance (0.01) between human capital and the head of structural money, as well as between the head of structural money and competitive advantage, and at a level of significance (0.05) among all human capital, capital relations between competitive advantage from the standpoint of personnel management of sports activity.

\section{Discuss the results}

It is seen from the table numbers (2-3) and the presence of correlation statistically significant at the level of significance $(0.01)$ between human capital and the head of structural money, as well as between the head of structural money and competitive advantage, and at a level of significance (0.05) among all human capital, Ras Relations between the capital and the competitive advantage from the viewpoint of the members of the boards of directors and management staff sports activity

In this regard, mention Ghen, Jin, Zhahuizhu \& Yuanxie (2004) the importance of intellectual capital it represents a competitive advantage for the organization, because organizations today compete on the basis of knowledge, information and skills that have to represent this critical source of competitive advantage, as well as, the intellectual capital is the most important sources of wealth of the organizations, but interest in it is a case of inevitability imposed by the nature of contemporary scientific and technological challenge. (11:5)

And confirms Martzan Martinez-torres (2006) that intellectual capital is the product of elements and components of community interaction, where human capital positively affect the top of structural money since it is the source of creativity and strategy update, and then the head of structural money building is the result of human creativity, as The restructuring of knowledge assets can turn individual expertise to collective ownership to achieve the organization's interest in converting human capital to capital structural owned by the organization, and the capital ties is to the ability to interact positively with members of the organization to stimulate the potential, which Aadyaly the creation of wealth, which in turn leads to human capital and structural capital increase, and lead the 
change in the surrounding SCO environment to a similar change in the relationship with the customer, and lead the change in environmental factors to push individuals to develop their abilities and skills, allowing them to adapt to new environmental changes and the associated relationships, and then capital relations in a positive impact on human capital. (13: 617)

And refers Stevenson MEP Stevenson, (2000) that the relationship between intellectual capital and knowledge management relationship close as two types of approved competition on the individual and on the strength of the minds of individuals, and that power can not be used in case of loss of the social fabric, which represents a combination of trust and cooperation, loyalty and help and attention. (15:1)

And it confirms both the Jescob and Helstorm Jacob, M., and T. Hellstorm Eds (2000), Jescob Eppler, M., (2003) that the intellectual capital leads an integral role with knowledge management, and this role is reflected in the active participation in the investigation organizational development and in achieving competitive advantage, and this is achieved through the active management of intellectual resources operations.

(12: 132) (10: 187)

The results of Hany Mohamed study (2006) (9) Impairment of efforts made by the organizations managing global in the field of electronics industry to keep workers those with creative capabilities and innovative by high, reflecting the existence of shortcomings on the part of the management of these organizations in dealing with the creative capabilities outstanding human resources

Also confirms the results of the uniforms Moses study (2010) (5) The intellectual capital is a basic pillar for the construction of economic progress in general, and the success of organizations in particular, the real capital which is owned by organizations is the intellectual capital and is in the knowledge that can be converted to value and decisions related to the head of intellectual capital is the decision $\mathrm{T}$ strategy as a means or a tool to achieve the objectives of the organization and management of knowledge assets is a powerful management tool

Marwa Farghaly Jaber (2013) (7) Investment in intellectual capital and is conducive to the development of some long-term benefits and increase the competitiveness of human resources is the mainstay which must Tstendalleha college to achieve competitive advantage

Ayman Suleiman Abu Sweireh (2015) (1) there is a near agreement on intellectual capital elements, and can resembles that group accumulated and a collage of knowledge, and every individual is seen by the knowledge that goes into his interest in a circle, that intellectual capital components mainly confined to three components, namely, (human capital - the head of structural money - capital Relations) 
Hamani Aziz (2015) (2) intellectual capital is the wealth of the institutions and individuals generating source together there is a positive relationship between human capital and the efficiency and performance of the financial institution, there is a positive relationship between the head of the structural capital efficiency and performance of the financial institution.

\section{Conclusions}

1- human capital among workers sports clubs in Alexandria of "scientific knowledge and expertise, innovation and teamwork capabilities and requirements are available and this leads to having clubs for human capital distinct

2- The head of structural money among workers sports clubs in Alexandria from "information and database systems, the development of administrative processes, policies and procedures are clear, the availability of administrative and training programs requirements are available, the clarity of the organizational structure and this leads to having clubs to the head of structural money distinct

3- capital requirements relations among workers sports clubs in Alexandria available "to provide reconnaissance system saw members of the quality of service provided, the periodic survey of competitive environment to learn about the services offered by the competitors and this leads to having Clubs capital relations are distinct

4- There is a relationship between human capital, the head of structural money, capital relationships and achieve competitive advantage for sports clubs in Alexandria.

\section{Recommendations}

- The need to deal with intellectual capital as a key strategic resource and among the various resources owned by sports clubs.

- The need for an evaluation of a regular routine of knowledge in sports clubs and linking evaluation results incentives and rewards and Alterqat system.

- The need to be careful clubs Alyy encourage team building, which has an important role to play in the top of the outstanding human capital formation contributes to achieving competitive advantage for sports clubs.

- Encourage cooperation and establish more alliances Alastrtejah and keep them and try to take advantage of the capabilities and expertise and would contribute to strengthening relations with the capital of sports clubs.

- The need for the sports clubs to support and encourage creativity and innovation by experimenting with innovative ideas and solutions provided by the workers and put them into practice. 


\section{References}

\begin{tabular}{|c|c|c|c|}
\hline 1 & 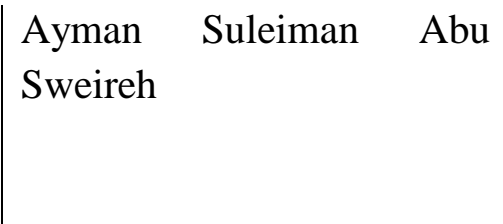 & : & $\begin{array}{l}\text { The basic elements of intellectual capital - an analytical } \\
\text { study, Journal of the Islamic University, economic and } \\
\text { administrative Studies, Vol. III and XX, the first issue, the } \\
\text { Gaza Strip, } 2015\end{array}$ \\
\hline 2 & Hamana Aziz & $:$ & $\begin{array}{l}\text { Spending on the contribution of intellectual capital in the } \\
\text { industrial enterprise performance - the case of Sonatrach } \\
\text { Foundation study, Faculty of Economic Sciences, Abu } \\
\text { Bakr Belcaid Tlemcen, Algeria } 2015 \text { University }\end{array}$ \\
\hline 3 & Sami Fayyad & $:$ & $\begin{array}{l}\text { Knowledge capital and its impact on the strategic reasons } \\
\text { for the success of the business organizations, the Sixth } \\
\text { Scientific Conference of the Faculty of Economics and } \\
\text { Administrative Alalomk, Zarqa Private University, 6-7, } \\
\text { Amman, Jordan, } 2008\end{array}$ \\
\hline 4 & Abdullah Kazim & $:$ & $\begin{array}{l}\text { The impact of the intellectual capital in the organizational } \\
\text { creativity, Qadisiya Journal of Science and economic } \\
\text { know-how, Volume } 10 \text { Issue } 3 \text {, College of Management } \\
\text { and Economics, Qadisiyah, Iraq } 0.2008 \text { University }\end{array}$ \\
\hline 5 & Lozi Musa & $:$ & $\begin{array}{l}\text { Knowledge management and investment in intellectual } \\
\text { capital to achieve excellence, research presented to the } \\
\text { development of intellectual capital, Kuwait Conference } \\
2010\end{array}$ \\
\hline 6 & $\begin{array}{l}\text { Mahmoud Ali Al Rosan, } \\
\text { Mahmoud } \\
\text { Ajlouni }\end{array}$ & $:$ & $\begin{array}{l}\text { The impact of intellectual capital in creativity in Jordanian } \\
\text { banks (field study), Damascus University Economic and } \\
\text { Legal Sciences Journal, Vol. 26, the second issue , } 2010\end{array}$ \\
\hline 7 & Marwa Jaber Farghaly & $:$ & $\begin{array}{l}\text { Investment Almwardalepeshrah to achieve competitive } \\
\text { advantage Faculty of Physical Education Girls Alascnddrah } \\
\text { University, Majstergarmnchorh message, Faculty of } \\
\text { Physical Althriph for girls, Alexandria University, } 2013\end{array}$ \\
\hline 8 & $\begin{array}{l}\text { Maan Almaadida and } \\
\text { Osman Mohamed }\end{array}$ & : & $\begin{array}{l}\text { The impact of operations knowledge capital management } \\
\text { and strategic innovation in the Sixth Scientific Conference } \\
\text { of the Faculty of Economics and Administrative Sciences } \\
\text { May 6-7 Zarqa Private University, Amman, Jordan, } 2008\end{array}$ \\
\hline
\end{tabular}




\begin{tabular}{|c|c|c|c|}
\hline 9 & Hany Mohamed Saeed & : & $\begin{array}{l}\text { Intellectual capital management as an entry point for the } \\
\text { development of the competitiveness of business } \\
\text { organizations, Garmnchorh Klahaltjarh PhD thesis, } \\
\text { University of the Suez Canal, } 2006\end{array}$ \\
\hline 10 & Eppler, M., & : & $\begin{array}{l}\text { Making Knowledge Visible through Knowledge Maps: } \\
\text { Concepts, Elements, Cases," in Holsapple, C. (Ed.), } \\
\text { Handbook on Knowledge Management (New York: } \\
\text { Springer, } 2003\end{array}$ \\
\hline 11 & $\begin{array}{l}\text { Ghen, Jin, Zhahuizhu \& } \\
\text { Yuanxie }\end{array}$ & : & $\begin{array}{l}\text { Measuring Intellectual Capital Anew Model and Empirical } \\
\text { Study", Journal of Intellectual Capital, Vol., 5, No., 1,2004 }\end{array}$ \\
\hline 12 & Jacob, M., and T. Hellstorm & $:$ & $\begin{array}{l}\text { The Future Knowledge Production in the Academy } \\
\text { (Buckingham: Open University Press , } 2000\end{array}$ \\
\hline 13 & Martinez-torres & $:$ & $\begin{array}{l}\text { A procdure to design a structural and measurement model } \\
\text { of intellectual capital an exploratory study "information } \\
\text { \&management ,2006 }\end{array}$ \\
\hline 14 & Mcgregor.j & $:$ & $\begin{array}{l}\text { tewed,d.and pach : Intellectual capital and coverate } \\
\text { governace new econmy bargin jornal of intellectual capital } \\
, 2004\end{array}$ \\
\hline 15 & Stevenson & : & $\begin{array}{l}\text { anew epistemological contex for education knowledge } \\
\text { management in public schools, } 2000 \text { journal of } \\
\text { instructional psychology vol }, 27\end{array}$ \\
\hline
\end{tabular}




\begin{abstract}
The study aimed to identify the intellectual capital role in supporting competitive advantage for sports clubs in Alexandria through human capital, structural, capital relations, the competitive advantage of sports clubs in Alexandria sports clubs in Alexandria, the researcher used the descriptive survey consisted of the study sample of board members Sports clubs and clubs, managers and directors of sports activities management (Ittihad - Olympy - Smouha - Sportnj- Steeds owners) and numbered (60) members, staff management physical activity clubs and numbered (52) member, and researchers used the questionnaire form a tool to collect data and information, was the use of appropriate statistical treatment The study found the need to deal with intellectual capital as a key resource and a strategic Among the various resources owned by sports clubs, the need for the sports clubs to support and encourage innovation processes and innovation by experimenting with ideas and innovative solutions provided by the workers and put them into practice.
\end{abstract}

